\begin{tabular}{|c|c|c|c|c|c|}
\hline JRL & Vol. 13 & No. 1 & Hal : $01-17$ & $\begin{array}{c}\text { Jakarta, } \\
\text { Juni 2020 }\end{array}$ & $\begin{array}{c}\text { p-ISSN : 2085.38616 } \\
\text { e-ISSN : 2580-0442 }\end{array}$ \\
\hline
\end{tabular}

\title{
IMPLEMENTASI ANALISIS SWOT DALAM PENENTUAN SUMBER AIR UNTUK PERTAMBANGAN NIKEL DI PULAU OBI, PROVINSI MALUKU UTARA
}

\author{
Taty Hernaningsih \\ Perekayasa Pusat Teknologi Lingkungan \\ Pusat Teknologi Lingkungan - BPPT \\ Email : tati.hernaningsih@bppt.go.id
}

\begin{abstract}
Abstrak
Pertambangan nikel di Pulau Obi, Provinsi Maluku Utara telah menggunakan sumber air dari Danau Karo yang berlokasi di dalam kawasan area pertambangan. Air diperlukan untuk kegiatan perusahaan pertambangan mencakup kebutuhan air bagi untuk tenaga kerja, proses pertambangan dan domestik. Jumlah pengambilan air terbesar berasal dari Danau Karo yang telah dilakukan secara terus menerus sehingga muka air danau tersebut mengalami penurunan. Kebutuhan air pertambangan nikel diwaktu yang akan datang makin bertambah sesuai dengan pengembangan pertambangan nikel. Potensi danau Karo sudah makin berkurang oleh karena itu perlu dilakukan pemanfaatan air dari sumber air lainnya di pulau Obi. Sumber air yang sudah dimanfaatkan di pulau Obi adalah mata air Kawasi, danau Loji, mata air Uluwatu, mata air Cermin dan yang belum dimanfaatkan adalah sungai Akelamo. Untuk mendukung kegiatan pertambangan nikel, maka perlu penambahan air dari sumber air tersebut. Metode untuk penentuan sumber air yang digunakan adalah SWOT (strength, weakness, opportunity, threats). Dalam melaksanakan metoda ini perlu dilakukan kesepakatan dari ahli dalam menentukan faktor internal dan eksternal serta skala nilainya. Hasil analisis SWOT akan memberikan solusi sumber air yang tepat, baik dari segi kuantitas maupun kualitasnya.
\end{abstract}

kata kunci: SWOT (strengths, weaknesses, opportunities, dan threats) 


\title{
IMPLEMENTATION OF SWOT ANALYSIS IN DETERMINING WATER SOURCES FOR NICKEL MINING IN OBI ISLAND, NORTH MALUKU PROVINCE
}

\begin{abstract}
Nickel mining on Obi Island, North Maluku Province has used water sources from Lake Karo, which is located within the mining area. Water demand for mining company activities includes water requirements for labor, mining and domestic processes. The largest amount of water withdrawal from Lake Karo has been done continuously so that the lake's water level has decreased. The water demand for nickel mining water in future will increase in accordance with the development of nickel mining. The potential of Karo Lake has diminished, it is necessary to use water from other water sources on Obi Island. Water resources that have been utilized on the island of Obi are Kawasi springs, Loji lakes, Uluwatu springs, Cermin springs and the untapped is Akelamo river. To support nickel mining activities, it is necessary to add water from these water resources. The method for determining the water source used is SWOT which stands for strengths, weaknesses, opportunities, and threats. In carrying out this method an agreement needs to be done from the expert in determining internal and external factors and the scale of the value. The result of SWOT analysis will provide the right water resource solutions, both in terms of quantity and quality.
\end{abstract}

keywords: SWOT (strengths, weaknesses, opportunities, dan threats) 


\section{PENDAHULUAN}

Searah dengan pelaksanaan
otonomi daerah, kabupaten/kota dipacu untuk dapat mandiri dalam mengelola sumber alam daerahnya. Sebagai contohnya Pemerintah Daerah Kabupaten Hamahera Selatan, Provinsi Maluku Utara memberikan kesempatan untuk mengelola Pulau Obi kepada pihak swasta. Salah satu dari industri swata yang telah melakukan kegiatan tersebut adalah Pabrik Pengolahan dan Pemurnian Bijih Nikel yang sudah menggunakan air dari Danau Karo. Lkasi sumber ini tidak jauh dari lokasi proses pengolahan nikel dan masih berada di dalam kawasan usaha pertambangan. Danau Karo adalah danau alami yang terletak di Pulau Obi, atau bisa disebut juga Pulau Obira yang merupakan pulau terbesar yang terletak di gugusan Kepulauan Obi.

Kebutuhan air kegiatan perusahaan pertambangan mencakup kebutuhan air bagi tenaga kerja, proses pertambangan dan domestik. Kebutuhan air tenaga kerja juga menggunakan standar kebutuhan air domestik tiap orang sebanyak 100 liter/hari. Sedang untuk kebutuhan air proses pertambangan disesuaikan dengan rencana penambahan PLTU dan unit pengolahan nikel. Kebutuhan air total saat ini, yang mencakup kebutuhan domestik dan non domestik, dalam setahun mencapai 0,045 juta $\mathrm{m}^{3}$ dan pada tahun 2020 akan meningkat menjadi 0,048 juta $\mathrm{m}^{31)}$.
Total kebutuhan air untuk kegiatan pertambangan tahun 2019 sebanyak 3,80 juta $\mathrm{m}^{3}$ dalam setahun. Pada Tahun 2020 adanya pertambahan operasi PLTU maka total kebutuhan air kegiatan pertambangan di lokasi ini per tahun akan mencapai sebesar 22,21 juta $\mathrm{m}^{3}$. Untuk memenuhi keutuhan air kegiatan pertambangan tersebut memanfaatkan keberadaan Danau Karo yang terletak kurang lebih $5 \mathrm{~km}$ di sebelah Utara sebagai tempat penampungan air. Kondisi eksisting disekitar danau Karo dapat dilihat pada peta kawasan hutan pada Gambar 1, dimana berdasarkan

peta tersebut kawasan hutan yang berpengaruh terhadap terhadap ketersediaan air danau adalah Karo lake catchment, Akelamo catcment, AKE Kawasi catchment. Sebelah Barat dari Danau Obi terdapat satu sungai besar yang bermuara di Danau Karo yang memberikan masukan air pada danau tersebut. Dua daerah aliran sungai di dekatnya pertambangan nikel adalah Daerah Aliran Sungai Toguraci dengan luasan $21 \mathrm{Km}^{2}$ dan Daerah Aliran Sungai Danau Karo ini berdampingan. Potensi air permukaan di Danau Karo tersedia sepanjang tahun dan diperkirakan mencapai 62,23 juta $\mathrm{m}^{3}$. Sumber air lainnya di P. Obi yang sudah dimanfaatkan oleh perusahaan pertambangan nikel adalah mata air Kawasi, danau Loji, mata air Uluwatu dan mata air Cermin. Sumber air yang kapasitasnya besar dan yang belum dimanfaatkan adalah sungai Akelamo. 


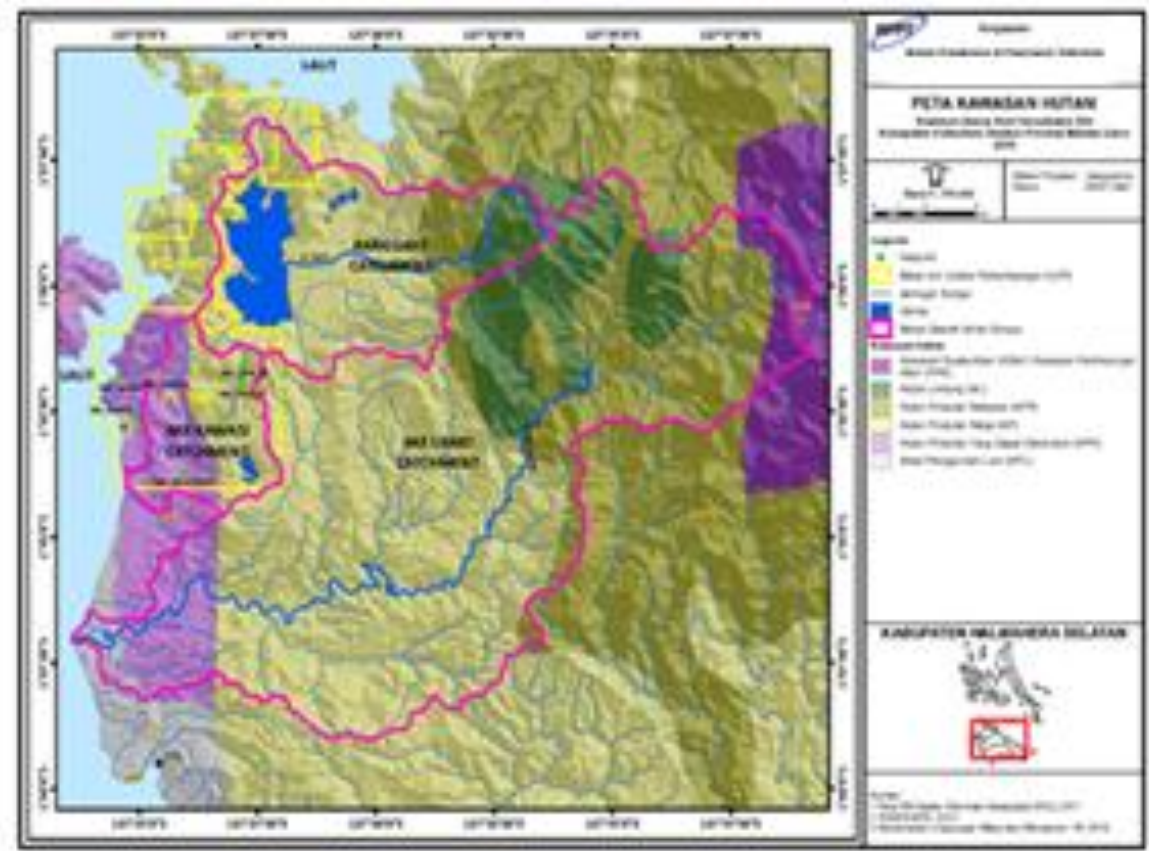

Gambar 1. Peta Kawasan Hutan untuk Wilayah Danau Karo dan sekitarnya

\begin{tabular}{lrr}
\multicolumn{2}{r}{ Pengambilan air yang terus } \\
menerus dari danau & Karo \\
mengakibatkan kapasitasnya makin & man \\
berkurang. Seiring dengan rencana & renatan \\
pengembangan & kegiatan \\
pertambangan & nikel & yang
\end{tabular} membutuhkan peningkatan pengadaan air maka perlu diperhitungkan bagaimana perubahan kesetimbangan air Danau Karo, termasuk penggunaan air Danau Karo oleh perusahaan lainnya yang berlokasi di bagian utara Danau Karo.

Permasalahaannya adalah mencari tambahan sumber air yang sesuai untuk memenuhi kebutuhan air di pertambangan di Pulau Obi tersebut. Beberapa cara dapat digunakan untuk mendapatkan solusi dalam mementukan sumber air yang dapat digunakan perusahaan tersebut, diantaranya dengan analisa SWOT. Metode untuk penentuan sumber air yang digunakan adalah SWOT dan SWOT merupakan singkatan strength (kekuatan), weakness (kelemahan), opp ortunity (peluang), dan threats (ancaman). Dalam melaksanakan metoda ini perlu dilakukan kesepakatan dari ahli dalam menentukan faktor internal dan eksternal serta skala nilainya. Analisa SWOT mempunyai kelebihan karena mempertimbangkan faktor-faktor internal dan eksternal yaitu mengevaluasi kelemahan dan menggunakan kekuatan untuk menghadapi ancaman, sekaligus menganalisa, menciptakan, dan mengambil semua peluangnya. ${ }^{2,3}$ )

Sehubungan dengan penjelasan tersebut di atas maka analisis SWOT akan diimplementasikan dalam penentuan alternatif pemenuhan kebutuhan air perusahaan pertambangan nikel Pulau Obi, provinsi Maluku Utara.

\section{METODOLOGI}

Metodologi yang digunakan dalam melaksanakan kajian penentuan alternatif pemenuhan pemenuhan kebutuhan air pertambangan nikel, Pulau Obi, provinsi Maluku Utara adalah sebagai berikut: 
1) Pengumpulan data sekunder dikumpulkan dari berbagai hasil studi yang pernah dilaksanakan oleh institusi berwenang dan data pustaka lainnya, antara lain: peta penggunaan lahan, peta pengembangan wilayah, topografi, pedoman analisis SWOT dan lainlain.

2) Pengumpulan data primer berasal dari pengukuran di lapangan yang meliputi: kualitas air, kuantitas air, penggunaan drone dan tanya jawab langsung ke masyarakat sekitar dan staf perusahaan.

3) Pelaksanaan analisa SWOT, dengan tahapan sebagai berikut:

- Menentukan faktor internal dan eksternal yang mempengaruhi sumber air. .

- Melakukan diskusi untuk menentukan skala nilai.
- Menerapkan skala nilai pada faktor internal dan eksternal.

- Melaksanakan Analisa SWOT.

\section{KAJIAN SUMBER AIR YANG SUDAH DIMANFAATKAN DAN KUALITAS SUMBERNYA DI PULAU OBI}

Kajian Potensi sumber air di pulau Obi yang akan dimanfaatkan untuk pemenuhan kebutuhan perusahaan pertambangan nikel adalah danau Karo, sungai Akelamo, mata air Kawasi, danau Loji dan mata air Cermin ${ }^{5)}$.

Berdasarkan data yang telah dikumpulkan dilapangan maka diketahui sumber air yang dapat dimanfaatkan beserta data rinci seperti debit hasil pengukuran dan pemanfaatan sumber. Rincian data disampaikan pada tabel 1 .

Tabel 1. Sumber Air di Pulau Obi yang akan dimanfaatkan

\begin{tabular}{|l|c|c|l|}
\hline Sumber Air & $\begin{array}{c}\text { Debit } \\
\text { Pengukuran } \\
\mathbf{2 0 1 9} \\
\text { (I/dt) }\end{array}$ & $\begin{array}{c}\text { Debit Setelah } \\
\text { Adjustment } \\
\text { Loss 20\% } \\
\text { (I/dt) }\end{array}$ & \multicolumn{1}{|c|}{ Pemanfaatan Sumber } \\
\hline Akelamo & - & - & Belum dimanfaatkan \\
\hline MA Kawasi & 46 & 36,8 & Masyarakat Desa Kawasi \\
\hline MA Loji 1 & 12 & 9,6 & Perusahaan pertambangan nikel. \\
\hline MA Loji 2 & 6 & 4,8 & Belum digunakan \\
\hline MA Cermin & 2,79 & 2,23 & Perusahaan pertambangan nikel. \\
\hline MA Karo & 5,42 & 4,33 & Perusahaan pertambangan nikel. \\
\hline MA Uluwatu & 60 & 48,00 & Belum digunakan \\
\hline S. Karo & - & 50 & Yang dimanfaatkan \\
\hline
\end{tabular}

Sumber: Kajian Kecukupan Sumber Mata Air Kawasi dan Loji, 2019

Tabel 2. Kualitas Sumber Air di Pulau Obi yang akan dimanfaatkan

\begin{tabular}{|l|c|c|c|c|c|}
\hline Sumber Air & $\mathbf{p H}$ & $\begin{array}{c}\text { Konduktivitas } \\
(\mathbf{m S} / \mathbf{m l})\end{array}$ & $\begin{array}{c}\text { TDS } \\
(\mathbf{m g} / \mathbf{l})\end{array}$ & $\begin{array}{c}\text { BOD } \\
\mathbf{( m g / l} \\
\mathbf{)}\end{array}$ & $\begin{array}{c}\text { COD } \\
(\mathbf{m g} / \mathbf{l})\end{array}$ \\
\hline Akelamo & & & 78 & 1,58 & 1,44 \\
\hline MA Kawasi & $5-8$ & & 92 & & \\
\hline MA Loji 1 & $5-6$ & 56,3 & 37,3 & & \\
\hline MA Loji 2 & $5-6$ & 56,3 & 37,3 & & \\
\hline MA Cermin & & $319 \mu \mathrm{S} / \mathrm{cm}$ & 215 & & \\
\hline Danau Karo & & & 0,65 & 1,94 & 76 \\
\hline MA Uluwatu & - & - & - & - & - \\
\hline S. Karo & & & & & \\
\hline
\end{tabular}

Sumber: Kajian Kecukupan Sumber Mata Air Kawasi dan Loji, 2019 


\section{PEMBAHASAN}

\subsection{Faktor Internal dan Eksternal}

Faktor internal adalah faktor-faktor yang berasal dari dalam suatu sumber yang melmpunyai kekuatan kelemahan, peluang dan ancaman dari sumber air. Adapun beberapa hal yang merupakan bagian dari faktor internal adalah;

- Kuantitas air

- Kualitas air

- Teknologi pengolahan air

- Jarak sumber ke pemakai

- Kondisi lingkungan kawasan

- Status lahan

Sedangkan beberapa hal yang merupakan bagian dari faktor eksternal yang berasal dari luar suatu sumber, yang mempunyai, kekuatan, kelemahan, peluang dan ancaman dari sumber air. Adalah sebagai berikut:

- Peraturan Pemerintah

- Harga produk

- Penggunaan air untuk penduduk

- Pembuangan air limbah

- Pembukaan hutan

- Pengelolaan sungai

- Pengembangan pertambangan

- Kepercayaan pemerintah

\subsection{Analisis SWOT}

Analisa SWOT untuk penentuan sumber air perusahaan pertambangan nikel, meliputi analisis terhadap:

1) Pemanfaatan Sungai Akelamo

2) Pemanfaatan Danau Karo

3) Pemanfaatan Kawasan mata air Kawasi

4) Pemanfaatan Kawasan mata air Uluwatu

5) Pemanfaatan Kawasan mata air Cermin

6) Pemanfaatan Danau Loji

Penjelasan analisis SWOT dengan mempertimbangkan faktor-faktor internal dan eksternal yang terdapat dari masingmasing sumber air untuk penentuan sumber air perusahaan pertambangan nikel adalah sebagai berikut:
1) Pemanfaatan Sungai Akelamo Untuk Pemenuhan Kebutuhan Air Perusahaan Pertambangan Nikel

- Strength

Adalah kekuatan yang dijadikan sebagai modal dasar: Pemanfatan Sungai Akelamo untuk keperluan perusahaan pertambangan nikel dengan bentuk kekuatan untuk mampu bersaing dengan berbagai alternatif pemanfaatan dari sumber air yang lain yang ada di sekitar wilayah itu.

a) Kualitas : Sungai Akelamo memiliki kualitas air baik dengan semua parameter fisika,kimia dan mikrobiologi memenuhi baku mutu air baku berdasarkan Peraturan Pemerintah No.82/2001 tentang Kualitas Air dengan TDS $=78 \mathrm{mg} / \mathrm{l}$, sedangkan nilai $B O D=1,58 \mathrm{mg} / \mathrm{l}$ dan $\mathrm{COD}=1,44 \mathrm{mg} / \mathrm{l}^{4}$ ).

b) Kuantitas: Kawasan Sungai Akelamo mengalir di daerah cakupan yang cukup luas dengan kuantitas besar yaitu 10.000 l/detik ${ }^{6}$.

c) Kondisi Lingkungan Kawasan: Kondisi lingkungan masih dalam kawasan area pertambangan nikel, sebagian di area hutan, stabilitas lereng yang baik, erosi yang terjaga baik longsor pada lereng pada dinding terjal, maupun erosi permukaan lahan maupun parit.

d) Teknologi : Ini berkaitan dengan teknologi yang digunakan untuk mengolah sumber air, maka secara teknologi untuk mengolah air dari sumber air sungai Akelamo tidaklah rumit karena sudah memenuhi baku mutu sumber air baku air minum dan dapat dipastikan bahwa biaya pengolahan murah.

e) Penggunaan untuk Penduduk: Saat ini penduduk sekitar belum memanfaatkan air sungai Akelamo.

f) Jarak : Jalur sungai Akelamo mendekati perusahaan tambang sehingga dapat ditentukan jarak terdekat sumber air dari sungai 
Akelamo dan titik pemanfaatan peruhaan perusahaan pertambangan nikel.

g) Harga Produk: Kualitas air baik sehingga ongkos produksi untuk mengolah air dari sumber Akelamo akan menjadi tidak terlalu mahal, sehingga produk akan menjadi pilihan yang menguntungkan baik bagi pengusaha maupun pemakai (user).

\section{- Weakness}

Kekurangan menjadikan motivasi untuk upaya mempertahankan kuantitas dan kualitasnya :

a) Status Lahan: Kejelasan mengenai status lahan menjadi pertimbangan yang utama dalam rangka pemanfaatan air dari sungai Akelamo, karena daerah hulu sungai bukan merupakan milik perusahaan pertambangan nikel sehingga jika siapa saja yang membutuhkan air dapat menyadap air dibagian hulu dan mengakibatkan berkurangnya kuantitas air yang mengalir di area perusahaan pertambangan nikel.

b) Pembuangan air limbah : Jalurnya mendekati lokasi perusahaan pertambangan nikel mempunyai kemungkinan air sungai dapat tercemar dan kualitasnya menurun karena adanya pembuangan air limbah dari pertambangan nikel yang belum diolah.

c) Pembukaan Hutan di area perusahaan pertambangan nikel: meningkatnya penggunaan areal hutan untuk pertambangan nikel akan mengganggu debit air sungai Akelamo dan terjadinya erosi sisi sungai.

\section{- Opportunities}

Kesempatan atau peluang yang dapat dibidik terhadap Pemanfaatan Sungai Akelamo :

\section{a) Kebutuhan/Kesempatan}

Memanfaatkan secara optimal air sungai Akelamo yang belum dimanfaatkan masyarakat. b) Mengelola sungai: Melakukan pengelolaan sungai Akelamo sehingga dapat menunjukkan ke pemerintah bahwa upaya pengelolaan yang dilakukan terhadap sungai Akelamo dapat bermanfaat bagi lingkungan yaitu upaya penghijauan dan perlindungan lahan terhadap erosi dan tanah longsor.

c) Pengembangan pertambangan: Kesempatan menunjukkan ke pemerintah bahwa dalam melakukan pengembangan area pertambangan dengan tidak melanggar peraturan yang berkaitan dengan kelestarian sungai.

\section{- Threat}

Analisa terhadap beragam ancaman yang akan selalu dihadapi.

a) Penurunan Kuantitas Air Akibat Manusia: Penurunan terhadap kuantitas air yang terjadi akibat pemanfaatan hutan untuk keperluan masyarakat di luar area kepemilikan perusahan nikel yang terletak DAS sungai Akelamo sehingga pengurangan kapasitas air sungai cepat terjadi.

b) Penurunan Kuantitas Air Akibat Alam: Ancaman yang utama adalah dari alam, ini akan terjadi jika jumlah hujan yang turun berkurang, sehingga akan semakin banyak jumlah bulan defisit. Dengan semakin banyaknya jumlah bulan defisit akan mengurangi debit limpasan air yang masuk kesungai.

c) Peraturan Pemerintah: Ancaman timbul karena adanya peraturan pemerintah yang mengijinkan masyarakat menggunakan sumber air sungai Akelamo dan membatasi perusahaan dalam pengambilan air sungai.

\section{- Strategi}

Strategi yang harus dilaksanakan antara lain: 
a) Harus ada kejelasan mengenai status lahan, agar kendala manajemen pemanfaatan air sungai dapat diatasi.

b) Melakukan promosi terhadap kawasan bahwa dikawasan tersebut telah berhasil dilakukan konservasi lingkungan yang berhasil, yang ditunjukkan dengan keberhasilan dalam penghijauan, perlindungan terhadap erosi, sedimentasi sehingga pemerintah tidak melarang penggunaan air sungai.

c) Pengelolaan DAS sungai Akelamo secara tepat dan berani melakukan evaluasi untuk hasil yang lebih baik sehingga kapasitas air sungai tidak cepat berkurang.

d) Kerjasama melestarikan DAS sungai Akelamo akan dapat mempertahankan kuantitas dan kualitas lingkungan di sungai Akelamo sehingga kualitas produk akan dapat terjaga dengan baik.

e) Mengikuti peraturan yang berisi baku mutu aliran yang diijinkan masuk ke sungai Akelamo sehingga dapat menjaga kualitas air dari sungai terhindar dari pencemaran air.

\section{2) Pemanfaatan Danau Karo Untuk Pemenuhan Kebutuhan Air Perusahaan Pertambangan Nikel}

\section{- Strength}

Adalah kekuatan yang dijadikan sebagai modal dasar: Pemanfaatan Danau Karo Untuk sumber air perusahaan pertambangan nikel dalam bentuk kekuatan untuk mampu bersaing dengan berbagai alternatif dari sumber air yang lain yang ada di sekitar wilayah itu.

a) Kualitas: sumber air dari Danau Karo memiliki kualitas air kualitas air baik dengan semua parameter fisika, kimia dan mikrobiologi memenuhi baku mutu air baku air minum Peraturan Pemerintah tetang Kualitas air no 82/2001. Tetapi kualitas air danau dapat berubah kualitasnya akibat proses berasal dari dasar danau maupun dari limpasan air permukaan di sekitar daerah tangkapan air. Kualitas danau Karo yaitu $\mathrm{BOD}=0,65 \mathrm{mg} / \mathrm{l}, \mathrm{COD}=1,94$ $\mathrm{mg} / \mathrm{l}$ dan TDS= $76 \mathrm{mg} / \mathrm{l}$.

b) Kuantitas: Sumber air dari Danau Karo memiliki kuantitas yang baik, hal ini dibuktikan dengan hasil analisis neraca air dengan kapasitas yang cukup besar dan yang sudah diambil dari Karo 1 dan Karo 2 adalah 5,46 I/detik dan 1,10 I/detik, selalu ada aliran meskipun pada kondisi bulan defisit defisit (Curah Hujan dikurangi Penguapan hasilnya negatif) dalam 2 bulan berturut-turut. Tetapi pengambilan oleh perusahaan pertambangan yang terus meningkat dari tahun ketahun menyebabkan air danau cepat berkurang, ini dapat dilihat dari turunnya permukaan air danau sejak tahun 2017.

c) Kondisi Lingkungan Kawasan: Kondisi lingkungan kawasan masih terlindung, ada hutan, stabilitas lereng yang baik, erosi yang terjaga baik longsor pada lereng pada dinding terjal, maupun erosi permukaan lahan maupun parit.

d) Teknologi : Ini berkaitan dengan teknologi yang digunakan untuk mengolah sumber air, maka secara teknologi untuk mengolah air dari sumber air Danau Karo dibutuhkan pengolahan air sederhana untuk menurunkan kesadahan dan COD, serta proses desinfeksi.

e) Penduduk: Saat ini penduduk sekitar belum memanfaatkan air danau Karo.

f) Program Perusahaan Pertambangan Nikel: Saat ini perusahaan pertambangan telah menggunakan air Danau Karo untuk kebutuhan domestik dan produksi dengan debit $0,167 \mathrm{~m}^{3} / \mathrm{det}$ dan penelitian telah dilakukan untuk mempertahankan kapasitas danau.

g) Harga Produk: Kualitas air cukup baik sehingga ongkos produksi untuk mengolah air dari sumber Danau Karo akan menjadi tidak terlalu mahal, sehingga produk akan menjadi pilihan 
yang menguntungkan baik bagi pengusaha maupun pemakai (user)

\section{- Weakness}

Kekurangan menjadikan motivasi untuk upaya mempertahankan kapasitas dan kualitasnya :

a) Status Lahan: Kejelasan mengenai status lahan menjadi pertimbangan yang utama dalam rangka pemanfaatan air dari Danau Karo, karena peruntukan lahan danau Karo sebagai hutan produksi sehingga siapa saja boleh memanfaatkan air danau.

b) Pembukaan Hutan: meningkatnya penggunaan areal hutan untuk pertambangan nikel sehingga curah hujan berkurang dan menurunnya kualitas air akibat erosi dan adanya sedimen yang menurunkan kualitas air.

c) Jarak : Jarak antara titik sumber air dari Danau Karo dan titik pemanfaatan perusahaan pertambangan nikel relatif jauh yaitu $5.164 \mathrm{~m}$ sehingga biaya pengambilan air sedikit mahal.

\section{- Opportunities}

Kesempatan atau peluang yang dapat dibidik terhadap Pemanfaatan Danau Karo sebagai sumber air perusahaan pertambangan nikel

\section{a) Kebutuhan/Kesempatan}

Kesempatan untuk memanfaatkan sumber air dari Danau Karo merupakan sebuah peluang yang terbaik sebab perusahaan pertambangan nikel membutuhkan air yang sangat banyak terutama untuk proses penambangan nikel.

b) Saat yang tepat : Penanaman Tanaman Sekitar Danau Karo oleh perusahaan pertambangan nikel ini merupakan saat yang tepat untuk dapat menunjukkan kepada masyarakat dan pemerintah bahwa upaya pengelolaan yang dilakukan terhadap danau Karo dapat bermanfaat bagi lingkungan yaitu upaya penghijauan dan perlindungan lahan terhadap erosi dan tanah longsor.

c) Kepercayaan Pemerintah: Perusahaan pertambangan nikel melakukan penelitian terhadap danau Karo sebagai usaha melestarikan sumber air akan merupakan peluang yang memberikan kepercayaan kepada pemerintah.

\section{- Threat}

Analisa terhadap beragam ancaman yang akan selalu dihadapi.

a) Penurunan Kuantitas Air Akibat Manusia: Penurunan terhadap kuantitas air yang terjadi akibat pemanfaatan hutan untuk keperluan masyarakat di luar area kepemilikan perusahan nikel yang terletak di DAS danau Karo sehingga pengurangan kapasitas danau cepat terjadi.

b) Penurunan Kuantitas Air Akibat Alam: Ancaman yang utama adalah dari alam, ini akan terjadi jika jumlah hujan yang turun berkurang, sehingga akan semakin banyak jumlah bulan defisit. Dengan semakin banyaknya jumlah bulan defisit curah hujan akan mengurangi debit limpasan.

c) Peraturan Pemerintah: Ancaman timbul karena adanya peraturan pemerintah yang membatasi sumber air danau Karo dapat menghambat perkembangan produksi pertambangan nikel.

\section{- $\quad$ Strategi}

Strategi yang harus dilaksanakan antara lain:

a) Melakukan promosi pengelolaan terhadap kawasan sehingga dikawasan tersebut telah berhasil dilakukan konservasi lingkungan yang berhasil, yang ditunjukkan dengan keberhasilan dalam penghijauan, perlindungan terhadap erosi, sedimentasi sehingga pemerintah tidak melarang penggunaan air Danau Karo.

b) Pengelolaan DAS Danau Karo secara tepat dan berani melakukan evaluasi 
untuk hasil yang lebih baik sehingga kapasitas debit danau tidak cepat berkurang. Salah satu caranya dengan artificial recharge danau Karo seperti: membuat kolam resapan.

c) Kerjasama melestarikan DAS danau Karo akan dapat mempertahankan kuantitas dan kualitas lingkungan sehingga kualitas produk akan dapat terjaga dengan baik.

d) Larangan untuk menebang hutan akan dapat menjaga kualitas air dari danau terhindar dari sedimentasi yang diindikasikan dengan kekeruhan yang tinggi dan bisa menurunkan kualitas air.

e) Jika kuantitas makin menurun dimasa yang akan datang maka perlu efisiensi pemakaian air yaitu dengan melakukan proses daur ulang terhadap air limbah yang sumber airnya dari danau Karo.

f) Alternatif lain untuk penambahan sumber air baku perusahaan pertambangan nikel yang makin berkurang dapat dilakukan dengan penggunaan air laut yang diproses dengan reverse osmosis.

\section{3) Pemanfaatan Danau Loji untuk Pemenuhan Kebutuhan Air Perusahaan Pertambangan Nikel}

\section{- $\quad$ Strength}

Adalah kekuatan yang dijadikan sebagai modal dasar: pemanfaatan danau Loji untuk sumber air perusahaan pertambangan nikel dalam bentuk kekuatan untuk mampu bersaing dengan berbagai alternatif dari sumber air yang lain yang ada di sekitar wilayah itu.

a) Kualitas: Sumber air dari danau Loji memiliki kualitas air yang cukup baik dengan hampir semua parameter memenuhi baku mutu berdasarkan Peraturan Pemerintah No.82/2001 tentang Kualitas Air. Kualitas air TDS $=37,3 \mathrm{mg} / \mathrm{l}$, kondutivitas $=56,3$ $\mathrm{mS} / \mathrm{ml}$ dengan $\mathrm{pH}$ 5-6.

b) Kuantitas: sumber air dari danau Loji terdiri atas mata air Loji 1 dan Loji 2 memiliki kuantitas tidak besar, hal ini dibuktikan dengan hasil analisis neraca air dengan debitnya masingmasing 9,6 l/detik dan 4,8 liter/detik.

c) Kondisi Lingkungan Kawasan: Kondisi lingkungan kawasan masih terlindung, ada pohon, stabilitas lereng yang baik, erosi yang terjaga baik.

d) Teknologi : Ini berkaitan dengan teknologi yang digunakan untuk mengolah sumber air, maka secara teknologi untuk mengolah air dari sumber air danau Loji dibutuhkan pengolahan air sederhana untuk menurunkan kesadahan, serta proses desinfeksi.

e) Program Perusahaan : Saat ini perusahaan pertambangan telah menggunakan air danau Loji untuk kebutuhan domestik dan produksi.

f) Jarak : Jarak antara titik sumber air dari danau Loji dan titik pemanfaatan Tailing Storage Facility perusahaan pertambangan nikel sekitar 1,2 km lokasi sebelah selatan relatif tidak jauh sehingga biaya pengambilan air dari danau tidak mahal, tetapi danau Loji 1 ke perusahaan sekitar $4.135 \mathrm{~m}$.

g) Harga Produk: Kualitas air cukup baik sehingga ongkos produksi untuk mengolah air dari sumber danau Loji akan menjadi tidak terlalu mahal, sehingga produk akan menjadi pilihan yang menguntungkan baik bagi pengusaha maupun pemakai (user)

\section{- Weakness}

Kekurangan menjadikan motivasi untuk upaya mempertahankan kapasitas dan kualitasnya ;

a) Status Lahan: Kejelasan mengenai status lahan menjadi pertimbangan yang utama dalam rangka pemanfaatan air dari danau Loji,

b) Kuantitas pengambilan: pengambilan oleh perusahaan pertambangan yang terus meningkat dari tahun ketahun menyebabkan air danau cepat berkurang. 
c) Pembukaan Hutan: meningkatnya penggunaan areal hutan untuk perusahaan pertambangan nikel sehingga curah hujan berkurang dan menurunnya kualitas air akibat erosi.

\section{- Opportunities}

Kesempatan atau peluang yang dapat dibidik terhadap pemanfaatan danau Loji sebagai sumber air perusahaan pertambangan nikel.

\section{1) Kebutuhan/Kesempatan}

Kesempatan untuk memanfaatkan sumber Air dari danau Lojii terutama mata air 2 yang belum dimanfaatkan, ini merupakan sebuah peluang yang terbaik sebab perusahaan pertambangan nikel membutuhkan air yang sangat banyak.

2) Kepercayaan Pemerintah : Penanaman tanaman Sekitar danau Loji oleh perusahan tambang ini merupakan saat yang tepat untuk dapat menunjukkan kepada masyarakat dan pemerintah bahwa upaya pengelolaan yang dilakukan terhadap danau Loji dapat bermanfaat bagi lingkungan yaitu upaya penghijauan dan perlindungan lahan terhadap erosi dan tanah longsor.

\section{- Threat}

Analisa terhadap beragam ancaman yang akan selalu dihadapi.

a) Penurunan Kuantitas Air Akibat Manusia: Penurunan terhadap kuantitas air yang terjadi akibat pemanfaatan hutan untuk keperluan masyarakat di luar area kepemilikan perusahan nikel yang terletak DAS danau Loji sehingga pengurangan kapasitas danau cepat terjadi.

b) Penurunan Kuantitas Air Akibat Alam: Ancaman yang utama adalah dari alam, ini akan terjadi jika jumlah hujan yang turun berkurang, sehingga akan semakin banyak jumlah curah hujan bulan defisit. Dengan semakin banyaknya jumlah bulan defisit akan mengurangi debit limpasan. c) Peraturan Pemerintah: Ancaman timbul jika ada peraturan pemerintah yang melarang penambahan penggunaan sumber air danau Loji dapat menghambat perkembangan produksi pertambangan nikel.

- Strategi

Strategi yang harus dilaksanakan antara lain:

a) Melakukan promosi pengelolaan terhadap kawasan sehingga dikawasan tersebut telah berhasil dilakukan konservasi lingkungan yang berhasil, yang ditunjukkan dengan keberhasilan dalam penghijauan, perlindungan terhadap erosi, sedimentasi sehingga pemerintah tidak melarang penggunaan air danau Loji

b) Pengelolaan DAS danau Loji secara tepat dan berani melakukan evaluasi untuk hasil yang lebih baik sehingga kapasitas debit danau tidak cepat berkurang.

c) Kerjasama melestarikan DAS danau Loji akan dapat mempertahankan kuantitas dan kualitas lingkungan sehingga kualitas produk akan dapat terjaga dengan baik.

d) Larangan untuk menebang hutan akan dapat menjaga kualitas air dari danau terhindar dari sedimentasi yang diindikasikan dengan kekeruhan yang tinggi dan bisa menurunkan kualitas air

4) Mata Air Kawasi untuk Pemenuhan Kebutuhan Air Perusahaan Pertambangan Nikel

\section{- Strength}

Adalah kekuatan yang dijadikan sebagai modal dasar: Pemanfaatan Pemanfaatan mata air Kawasi untuk sumber air perusahaan pertambangan nikel dalam bentuk kekuatan untuk mampu bersaing dengan berbagai alternatif dari sumber air yang lain yang ada di sekitar wilayah itu. 
a) Kualitas: sumber air dari mata air Kawasi mempunyai kualitas air yang dapat diandalkan dan berdasarkan hasil kajian kualitas sumber air yang berasal dari mata air Kawasi memenuhi baku mutu untuk sumber air baku air bersih berdasarkan Peraturan Pemerintah No.82/2001 tentang Kualitas Air dengan $\mathrm{pH}=6,5$ 8 dan TDS= 92 ppm ${ }^{7)}$.

b) Kuantitas: Kuantitas sumber air dari mata air Kawasi berfluktuasi dan saat pengukuran debitnya adalah $46 \mathrm{l} /$ detik.

c) Kondisi Lingkungan Kawasan: Kondisi lingkungan kawasan sebagian masih terindung dan sebagian sudah terbuka.

d) Teknologi : Ini berkaitan dengan teknologi yang digunakan untuk mengolah sumber air, maka secara teknologi untuk mengolah air dari sumber air mata air Kawasi sangat mudah dan dapat dipastikan bahwa biaya pengolahan murah yaitu hanya dengan proses desinfeksi.

e) Penduduk: Saat ini penduduk sekitar sudah memanfaatkan mata air Kawasi.

f) Jarak : Jarak antara titik sumber air ke perusahaan pertambangan nikel relatif tidak jauh yaitu $775 \mathrm{~m}$ ke perusahaan pertambangan nikel dan juga jarak ke pemukiman masyarakat tidak jauh sehingga biaya pengaliran air dari mata air tidak mahal.

g) Harga Produk: Kualitas air bagus menyebabkan ongkos produksi untuk mengolah air dari sumber mata air Kawasi akan menjadi murah, sehingga produk akan menjadi pilihan yang menguntungkan untuk dimanfaatkan.

\section{- Weakness}

Kekurangan menjadikan motivasi untuk upaya mempertahankan kapasitas dan kualitasnya ;

a) Kuantitas pengambilan: Debit air yang tersedia tidak besar, jika pengambilan air berlebihan maka akan berakibat pengaliran air dari mata air akan tergganggu. b) Pernurunan kualitas air: Adanya penebangan hutan untuk pengembangan perusahaan pertambangan nikel menyebabkan erosi sehingga sedimennya mempengaruhi kualitas air.

c) Penurunan kuantitas: Meningkatnya penggunaan areal hutan untuk perusahaan pertambangan nikel menyebabkan kuantitas berkurang .

\section{- Opportunities}

Kesempatan atau peluang yang dapat dibidik terhadap pemanfaatan mata air Kawasi sebagai sumber air perusahaan pertambangan nikel

a) Kebutuhan/Kesempatan:

Kesempatan untuk memanfaatkan sumber mata air Kawasi tetapi jumlahnya tidak mencukupi seluruh kebutuhan perusahaan pertambangan nikel karena mata air Kawasi sudah digunakan untuk keperluan masyarakat.

b) Saat yang tepat: Perusahaan pertambangan nikel mempunyai kesempatan menunjukkan ke pemerintah dan masyarakat telah memberikan infrastruktur untuk penyediaan air dari mata air untuk masyarakat sebagai salah satu tugasnya sebagai CSR .

c) Kepercayaan Pemerintah: Kesempatan memberi kepercayaan kepada Pemerintah dalam menangani atau mengelola mata air Kawasi ini sehingga juga dapat bermanfaat bagi masyarakat dan lingkungan.

- Threat

Analisa terhadap beragam ancaman yang akan selalu dihadapi.

a) Penurunan Kuantitas Air Akibat Manusia: Penurunan terhadap kuantitas mata air yang terjadi akibat penebangan hutan baik dikawasan perusahaan pertambangan nikel maupun dihulunya.

b) Penurunan Kuantitas Air Akibat Alam: Ancaman yang utama adalah 
dari alam, ini akan terjadi jika terjadi kerusakan DAS mata air karena bencana alam seperti gempa, longsor.

c) Pengambilan air tanpa koordinasi: Ancaman timbul karena tidak adanya pengontrolan pengambilan sumber air sehingga debit akan cepat berkurang.

- Strategi

Strategi yang harus dilaksanakan antara lain:

a) Pengelolaan mata air Kawasi secara tepat dan berani melakukan evaluasi untuk hasil yang lebih baik sehingga kapasitas debit danau tidak cepat berkurang.

b) Kerjasama melestarikan mata air Kawasi akan dapat mempertahankan kuantitas dan kualitas lingkungan mata air sehingga kualitas produk akan dapat terjaga dengan baik.

c) Larangan untuk menebang hutan akan dapat menjaga kualitas mata air terhindar dari sedimentasi yang diindikasikan dengan kekeruhan yang tinggi dan bisa menurunkan kualitas air.

d) Dibutuhkan pengolahan air sederhana dengan proses desinfeksi.

e) Tidak melakukan penggalian hingga lapisan fractured bedrock atau memotong airtanah. Jika penggalian dilakukan hingga lapisan bedrock, jalur aliran airtanah mata air Kawasi diduga akan terganggu.

f) Pengembangan tambang disarankan memiliki jarak minimum 250 meter dari mata air Kawasi.

5) Pemanfaatan Mata Air Uluwatu Untuk Pemenuhan Kebutuhan Air Perusahaan Pertambangan Nikel

\section{- $\quad$ Strength}

Adalah kekuatan yang dijadikan sebagai modal dasar: Pemanfaatan Pemanfaatan mata air Uluwatu untuk sumber air perusahaan pertambangan nikel dalam bentuk kekuatan untuk mampu bersaing dengan berbagai alternatif dari sumber air yang lain yang ada di sekitar wilayah itu.

a) Kualitas: sumber air dari mata air memiliki kualitas air yang dapat diandalkan, kualitas sumber air mata Air Uluwatu belum dianalisa tetapi sebagai sumber mata air umumnya kualitas airnya cukup baik .

b) Kuantitas: Mata air air dapat dipompa selama 24 jam dengan kuantitas sumber air dari mata air Uluwatu 48 l/detik.

c) Kondisi Lingkungan Kawasan: Kondisi lingkungan kawasan mata air Uluwatu sebagian terlindungi dan sebagian sudah terbuka.

d) Teknologi : Ini berkaitan dengan teknologi yang digunakan untuk mengolah sumber air, maka secara teknologi untuk mengolah air dari sumber air mata air Uluwatu sangat mudah dan dapat dipastikan bahwa biaya pengolahan murah yaitu hanya dengan proses desinfeksi.

e) Program Perusahaan Pertambangan Nikel: Perusahaan pertambangan nikel menggunakan mata air Uluwatu untuk memenuhi kebutuhan air bersih.

f) Jarak : Jarak antara titik sumber air ke perusahaan relatif dekat yaitu $3.666 \mathrm{~m}$ sehingga biaya pengambilan air dari mata air ke pengguna menjadi agak mahal.

g) Harga Produk: Kualitas air bagus menyebabkan ongkos produksi untuk mengolah air dari sumber mata air Uluwatu akan menjadi murah, sehingga produk akan menjadi pilihan yang menguntungkan baik bagi pengusaha maupun pemakai (user).

\section{- Weakness}

Kekurangan menjadikan motivasi untuk upaya mempertahankan kapasitas dan kualitasnya ;

a) Kuantitas pengambilan: Debit air yang tersedia cukup besar, jika pengambilan air berlebihan maka akan berakibat pengaliran air akan tergganggu. 
b) Pernurunan kualitas air: Adanya penebangan hutan untuk pengembangan perusahaan pertambangan nikel menyebabkan erosi sehingga sedimennya mempengaruhi kualitas air.

c) Penurunan kuantitas: meningkatnya penggunaan areal hutan untuk perusahaan pertambangan nikel memungkinkan kuantitas berkurang.

\section{- Opportunities}

Kesempatan atau peluang yang dapat dibidik terhadap pemanfaatan mata air uluwatu sebagai sumber air perusahaan pertambangan nikel :

a) Kebutuhan/Kesempatan

Kesempatan untuk memanfaatkan sumber mata air Uluwatu walaupun jumlahnya hanya memenuhi kebutuhan air bersih .

b) Kepercayaan Pemerintah: Untuk memberikan kepercayaan kepada Pemerintah maka dalam memanfaatkan mata air Uluwatu harus disertai pemeliharaan serta pengelolaan mata air ini sehingga tetap mempertahankan kelestarian lingkungan.

\section{- Threat}

Analisa terhadap beragam ancaman yang akan selalu dihadapi.

a) Penurunan Kuantitas Air Akibat Manusia: Penurunan terhadap kuantitas mata air yang terjadi akibat penebangan hutan baik dikawasan perusahaan pertambangan nikel maupun dihulunya. Selain itu pembangunan perusahaan yang memotong saluran mata air akan mengganggu kelangsungan mata air.

b) Penurunan Kuantitas Air Akibat Alam: Ancaman yang utama adalah dari alam, ini akan terjadi jika DAS mata air terkena bencana alam seperti gempa, longsor.

c) Pengambilan air tanpa koordinasi: Ancaman timbul karena tidak adanya pengontrolan pengambilan sumber air sehingga debit akan cepat berkurang.

- Strategi

Strategi yang dilaksanakan antara lain:

a) Pengelolaan mata air Uluwatu secara tepat dan berani melakukan evaluasi untuk hasil yang lebih baik sehingga kapasitas debit danau tidak cepat berkurang

b) Kerjasama melestarikan mata air Uluwatu akan dapat mempertahankan kuantitas dan kualitas lingkungan mata air sehingga kualitas produk akan dapat terjaga dengan baik.

c) Larangan untuk menebang hutan akan dapat menjaga kualitas mata air terhindar dari sedimentasi yang diindikasikan dengan kekeruhan yang tinggi dan bisa menurunkan kualitas air.

d) Dibutuhkan pengolahan air sederhana dengan proses desinfeksi.

e) Tidak melakukan penggalian hingga lapisan fractured bedrock atau memotong airtanah. Jika penggalian dilakukan hingga lapisan bedrock, jalur aliran airtanah mata air Uluwatu diduga akan terganggu.

f) Pengembangan tambang disarankan memiliki jarak minimum 250 meter dari mata air Uluwatu.

\section{6) Pemanfaatan Mata Air Cermin Untuk Pemenuhan Kebutuhan Air Perusahaan Pertambangan Nikel}

\section{- $\quad$ Strength}

Adalah kekuatan yang dijadikan sebagai modal dasar: Pemanfaatan Pemanfaatan mata air Cermin untuk sumber air perusahaan pertambangan nikel dalam bentuk kekuatan untuk mampu bersaing dengan berbagai alternatif dari sumber air yang lain yang ada di sekitar wilayah itu.

a) Kualitas: sumber air dari mata air memiliki kualitas air yang dapat diandalkan, berdasarkan hasil kajian kualitas sumber air mata Air Cermin 
mengandung TDS $=215$ ppm, electrical conductivity $319 \mu \mathrm{S} / \mathrm{cm}$.

b) Kuantitas: Mata air air dapat dipompa selama 24 jam dengan kuantitas sumber air dari mata air Cermin 2,23 I/detik.

c) Kondisi Lingkungan Kawasan: Kondisi lingkungan kawasan sebagian terlindungi dan sebagian sudah terbuka.

d) Teknologi : Ini berkaitan dengan teknologi yang digunakan untuk mengolah sumber air, maka secara teknologi untuk mengolah air dari sumber air mata air sangat mudah dan dapat dipastikan bahwa biaya pengolahan murah yaitu hanya dengan proses desinfeksi.

e) Program salah satu Perusahaan dalam Pertambangan Nikel: Perusahaan ini menggunakan mata air Cermin untuk memenuhi kebutuhan air bersih.

f) Jarak: Jarak antara titik sumber air ke peruhaan ini relatif dekat yaitu 1.192 m sehingga biaya pengambilan air dari mata air ke pengguna menjadi tidak mahal.

g) Harga Produk: Kualitas air bagus menyebabkan ongkos produksi untuk mengolah air dari sumber mata air Cermin akan menjadi murah, sehingga produk akan menjadi pilihan yang menguntungkan baik bagi pengusaha maupun pemakai (user)

\section{- Weakness}

Kekurangan menjadikan motivasi untuk upaya mempertahankan kapasitas dan kualitasnya ;

a) Kuantitas pengambilan: Debit air yang tersedia kecil, jika pengambilan air berlebihan maka akan berakibat pengaliran air akan tergganggu.

b) Pernurunan kualitas air: Adanya penebangan hutan untuk pengembangan perusahaan pertambangan nikel menyebabkan erosi sehingga sedimennya mempengaruhi kualitas air. c) Penurunan kuantitas: meningkatnya penggunaan areal hutan untuk perusahaan pertambangan nikel memungkinkan kuantitas berkurang.

\section{- Opportunities}

Kesempatan atau peluang yang dapat dibidik terhadap pemanfaatan mata air Cermin sebagai sumber air perusahaan pertambangan nikel :

a) Kebutuhan/Kesempatan

Kesempatan untuk memanfaatkan sumber mata air Cermin walaupun jumlahnya hanya memenuhi kebutuhan air bersih.

b) Kepercayaan Pemerintah: Untuk memberikan kepercayaan kepada Pemerintah maka dalam memanfaatkan mata air Cermin harus disertai pemeliharaan serta pengelolaan mata air ini sehingga tetap mempertahankan kelestarian lingkungan.

\section{- Threat}

Analisa terhadap beragam ancaman yang akan selalu dihadapi.

a) Penurunan Kuantitas Air Akibat Manusia: Penurunan terhadap kuantitas mata air yang terjadi akibat penebangan hutan baik dikawasan perusahaan pertambangan nikel maupun dihulunya.

b) selain itu pembangunan perusahaan yang memotong saluran mata air akan mengganggu kelangsungan mata air.

c) Penurunan Kuantitas Air Akibat Alam: Ancaman yang utama adalah dari alam, ini akan terjadi jika DAS mata air terkena bencana alam seperti gempa, longsor.

d) Pengambilan air tanpa koordinasi: Ancaman timbul karena tidak adanya pengontrolan pengambilan sumber air sehingga debit akan cepat berkurang. 


\section{- Strategi}

Strategi yang harus dilaksanakan antara lain:

a) Pengelolaan mata air Cermin secara tepat dan berani melakukan evaluasi untuk hasil yang lebih baik sehingga kapasitas debit danau tidak cepat berkurang

b) Kerjasama melestarikan mata air Cermin akan dapat mempertahankan kuantitas dan kualitas lingkungan mata air sehingga kualitas produk akan dapat terjaga dengan baik.

c) Larangan untuk menebang hutan akan dapat menjaga kualitas mata air terhindar dari sedimentasi yang diindikasikan dengan kekeruhan yang tinggi dan bisa menurunkan kualitas air.

d) Dibutuhkan pengolahan air sederhana dengan proses desinfeksi.

e) Tidak melakukan penggalian hingga lapisan fractured bedrock atau memotong airtanah. Jika penggalian dilakukan hingga lapisan bedrock, jalur aliran airtanah mata air Cermin diduga akan terganggu.

f) Pengembangan tambang disarankan memiliki jarak minimum 250 meter dari mata air Cermin.
Berdasarkan data di atas maka penilaian dari data kualitatif tersebut dilakukan kuantifikasi dengan suatu penilaian dengan model rating scale yang selanjutnya disebut dengan model skala nilai sehingga didapat skor pembobotan alternatif pemanfaatan dari masing-masing sumber air.

\subsection{HASIL ANALISA SWOT}

Berdasarkan hasil dari total skor pembobotan alternatif pemanfaatan dari masing-masing sumber air tabel tersebut maka ditempatkan dalam diagram seperti pada gambar 1 .

Dari gambar dapat disimpulkan analisis SWOT untuk pemanfaatan air sungai Akelamo sebagai sumber air baku untuk keperluan perusahaan pertambangan nikel mempunyai skor tertinggi, ini berarti pemanfaatan sungai Akelamo yang dipilih dan paling mungkin dapat dikembangkan untuk sumber air pada masa mendatang, mengingat debit danau Karo yang terus menurun debitnya. Jumlah potensi air yang besar menjadi kunci penentu, dengan rencana kebutuhan $10.000 \mathrm{l} /$ detik, sungai Akelamo mampu mensuplai sepanjang tahun, bahkan pada musim hujan tidak turun sama sekali. 


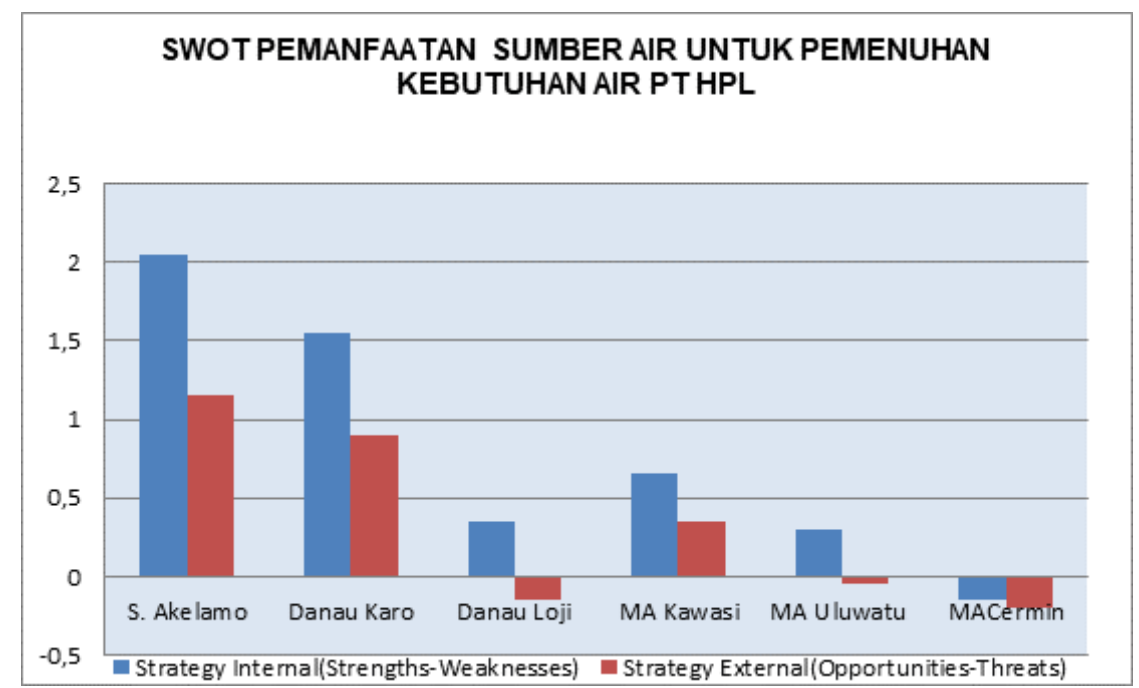

Gambar 2. Alternatif Pemanfaatan Sumber Air Untuk Pemenuhan

Kebutuhan Air

\section{KESIMPULAN}

Berdasarkan analisis menggunakan SWOT terhadap kondisi kuantitas dan kualitas dari sumber air sungai Akelamo, Danau Karo, Danau Loji, Mata Air Kawasi, mata air Uluwatu dan mata air Cermin maka ditetapkan alternatif pemanfaatan sungai Akelamo. Pemanfaatan sungai Akelamo yang mempunyai debit 10.000 I/detik untuk memenuhi kebutuhan air perusahaan pertambangan nikel akan memberi peluang yang tinggi dibanding sumber air danau Karo, danau Loji, mata air Kawasi, mata air Uluwatu dan mata air Cermin. Pertimbangan ini sudah termasuk ketersediaan air untuk masa mendatang dengan pengaliran yang kontinyu dan kualitas yang memenuhi baku mutu untuk air minum berdasarkan Peraturan Pemerintah No.82/2001 tentang Kualitas Air.

\section{Daftar Pustaka}

Laporan Rencana Peningkatan Kegiatan Penambangan, Pembangunan Dan Pengoperasian Pabrik Smelter Bijih Nikel Dan Sarana Penunjangnya PT Trimegah Bangun Persada Di Desa
Kawasi Kecamatan Obi Kabupaten Halmahera Selatan Provinsi Maluku Utara, 2016, PT Trimegah Bangun Persada.https://cpssoft.com/blog/bis nis/pengertian-analisis-swot/

https://www.maxmanroe.com/vid/bisnis/p engertian-analisis-swot.html

Andal, Rencana Peningkatan Kegiatan Dan Sarana Penunjangnya PT Trimegah Bangun Persada Di Desa Kawasi Kecamatan Obi Kabupaten Halmahera Selatan Provinsi Maluku Utara, September 2016. Penambangan, Pembangunan Dan Pengoperasian Pabrik Smelter Bijih Nikel.

Kajian Kecukupan Sumber Mata Air Site Kawasi Dan Loji, 2019, PT Trimegah Bangun Persada.

Bantuan Studi Kegiatan Neraca Sumber Daya Air Dan Rona Lingkungan Awal, Di Danau Karu, Pulau Obi, Kabupaten Halmahera Selatan, Prov. Maluku Utara, 2016 , Badan Pengkajian dan Penerapan Teknologi dan PT Wanatiara.M

Studi Hidrogeologi Mata Air Kawasi, Pulau Obi, Maluku Utara Pt. Trimegah Bumi Persada, September 2018, PT LAPI ITB. 